\title{
Factors Influencing Patterns of Cattle Graz- ing Behavior on Shortgrass Steppe
}

\author{
R.L. SENFT, L.R. RITTENHOUSE, AND R.G. WOODMANSEE
}

\begin{abstract}
Factors influencing distribution of free-roaming cattle were studied on shortgrass steppe in northeastern Colorado. Spatial units selected for grazing were plant communities (soil-plant associations) and a stock-watering area. Regression models of grazing patterns were derived for growing- and dormant-season grazing patterns. Seasonal-grazing distribution was correlated with proximity to water (1/distance) and site-quality indicators. Internal validation of seasonal-grazing models indicated a good fit of predicted to observed patterns. Because ad hoc regression models lack wide applicability, relationships between spatial preference and vegetation properties were investigated. Combined relative measures of forage quality and quantity were good predictors of community preference. Measures of relative biomass or frequencies of forage species were poor predictors of spatial preference. The high correlation between preference and properties of plants composing the bulk of the diet suggests an interaction between diet selection and selection of grazing areas. The highest correlation occurred between relative community preference and relative aboveground standing nitrogen (crude protein).
\end{abstract}

Animal distribution is considered an important component of livestock management. We have only generalities, no quantitative, predictive knowledge about what factors influence grazing-animal distribution, how those factors change over time, or how distribution is related to nutrition. Systematic investigation of mechanisms behind distribution of range livestock is lacking. Because distribution is traditionally described in terms of use of predetermined zones, areas actually selected by animals for grazing are often not known.

Predicting livestock distribution requires precise quantification of behavior and contributing environmental variables. This paper describes a study of spatial patterns of cattle grazing on shortgrass steppe. The objectives of this research were to determine (1) which spatial components of the landscape are selected as grazing habitat by cattle, (2) what factors influence spatial patterns of seasonal or

\footnotetext{
Authors are former graduate student and professors, Range Science Department, Colorado State University, Fort Collins 80523; Senft is currently assistant professor, Animal, Dairy and Veterinary Sciences Department, Utah State University, Logan 84322.

This research was supported in part by National Science Foundation Grant 7906009 and by the Colorado State University Experiment Station and is published as Scientific Series No. 2911

Manuscript accepted April 17, 1984.
}

subseasonal grazing, and (3) if selection of grazing areas is related to (nutritional) properties of the vegetation.

\section{The Study Area}

This study was conducted on the USDA-ARS Central Plains Experimental Range (CPER) in northeastern Colorado. The climate at CPER is semiarid with an average annual precipitation of $310 \mathrm{~mm}$. Normally, $70 \%$ of precipitation falls during the growing season; peak monthly precipitation occurs in May (Jameson, 1969).

The shortgrass steppe vegetation is dominated by blue grama [Bouteloua gracilis (H.G.K.) Lag.] and buffalo grass [Buchloe dactyloides (Nutt.) Engelm]. Other plant species are western wheatgrass (Agropyron smithii Rydb.), sedges (Carex spp.), pricklypear cactus (Opuntia polyacantha Haw.), spreading buckwheat (Eriogonum effusum Nutt.), fringed sagewort (Artemesia frigida Willrd.), broom snakeweed [Guterrezia sarothrae (Pursh) Britt. \& Rusby], and rabbitbrush [Chrysothamnus nauseosus (Pallus) Britt.]. Annual forbs are important constituents in wet years.

Grazing behavior was studied on a 125 -ha pasture with a ridge running diagonally through its center (Fig. la), and two intermittent drainages parallel to the ridge. Relief was approximately $24 \mathrm{~m}$. A closed basin, or playa, was situated southeast of the center, an exclosure in the center, and a stock-watering tank in the center of the north fenceline.

Six plant community types were identified (Fig. 1b) based on floristic composition, soil characteristics, and topographic position:

(1) Buda-Bogr (15.6\% of the study area) was predominantly composed of buffalo grass (Buda) and blue grama (Bogr). Vegetation was uniformly low (less than $10 \mathrm{~cm}$ ). Sedges compose about $15 \%$ of the herbage. Scarlet globemallow [Sphaeralcea coccinia (Pursh) Rydb.] was moderately abundant and occurred on broad, flat lowlands with poorly developed drainage channels. Soils were sandy clay loams of moderate depth.

(2) Buda-Agsm-Carex (11.8\% of the study area) consisted of a dense understory of buffalo grass and sedges and an overstory of western wheatgrass (Agsm). Some patches contained rabbitbrush and/or fringed sagewort. This type occurred in bottoms of intermittent drainages and in closed basins. Soils were deep $(60 \mathrm{~cm}$ or greater) with a clay loam or sandy clay loam texture.

(3) Agsm-Dist (8.0\% of the study area) had an overstory of 
a)

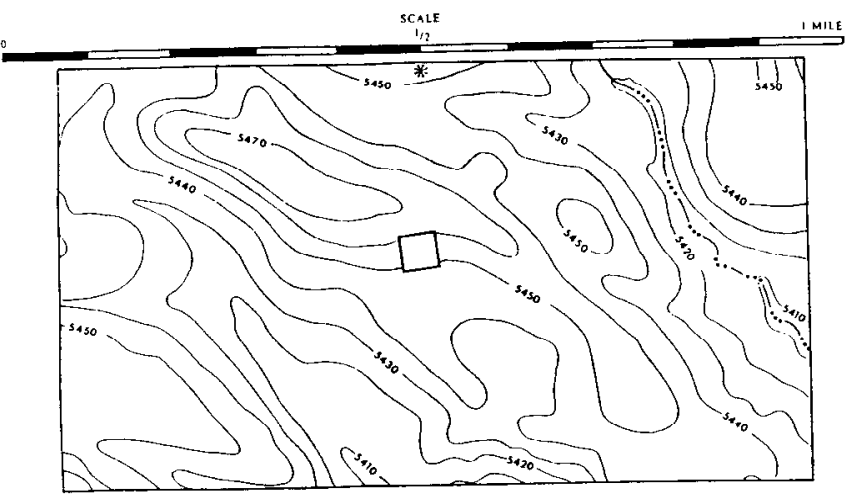

b)

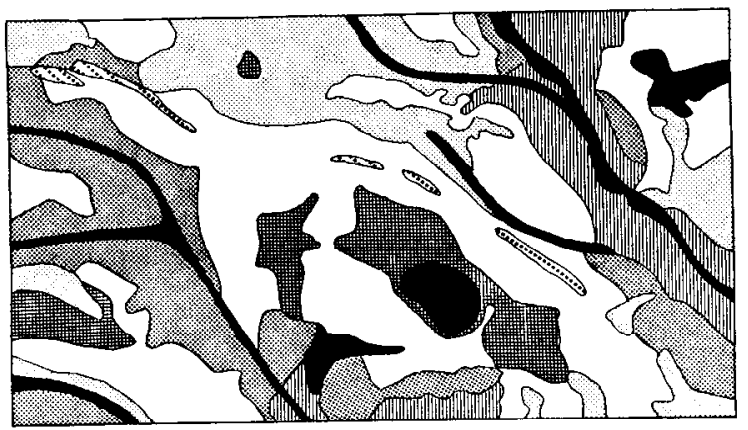

PLANT COMMUNITIES ON THE STUDY AREA

$\begin{array}{ll}\text { Buda-Bagr } & \text { Buda-Agsm-Carex } \\ \square \text { Bogr-Oppo } & \text { Bugr-Eref-Oppo } \\ & \text { Yucca }\end{array}$

Fig. 1. (A) Topography of the 125-ha study area, showing 10-ft contour intervals. Location of the stock-watering area is indicated by the asterisk (*).

(B) Plant communities were delineated on the basis of botanical composition, soil texture, topographic position and productivity. Community types are named for dominant plant species and/or site indicator species: Bogr = Bouteloua gracilis, Buda $=$ Buchloe dactyloides, $A g s m=$ Agropyron smithii, Carex $=$ spp., Oppo $=$ Opuntia polyacantha, Eref $=$ Eriogonum effusum, Dist $=$ Distichlis stricta, and Yucca - Yucca glauca.

western wheatgrass and saltgrass [Distichlis stricta (Torr.) Rydb.] western wheatgrass, and a sparse understory of blue grama, buffalo grass, and sedges. This type occurred in swales with saline soils adjacent to drainage channels. Soils were sandy loams of moderate depth.

(4) Bogr-Oppo (37.7\% of the study area) was dominated by blue grama and pricklypear cactus (Oppo) and was charactcrized by low productivity and patchy cover. Scarlet globemallow and fringed sagewort were relatively abundant. This type occurred on ridgetops and upper slopes and was the most widespread community on the area. Soils were shallow sandy loams.

(5) Bogr-Eref-Oppo (8.9\% of the study area), an upland type, had a patchy understory of blue grama and pricklypear cactus, and an overstory of spreading buckwheat (Eref) and sand dropseed [Sporobolus cryptandrus (Torr.) Gray]. This type was found on shallow, coarse soils on upper slope and ridgetop positions. Important inclusions were patches where blue grama had been destroyed by unknown disturbances. During the growing season, disturbed areas were occupied by peppergrass (Iepidium densiflorum chrad.) and beggarstick [Lappula redowskii (F. \& M.) Guerke].

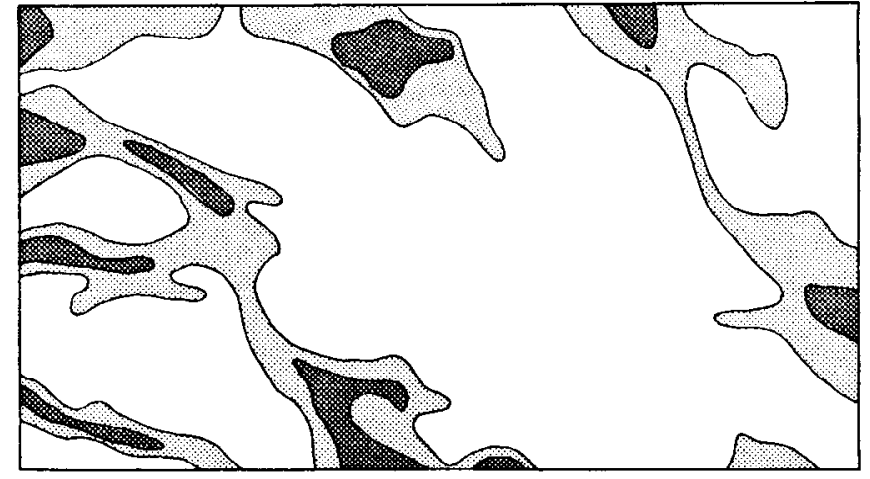

b)

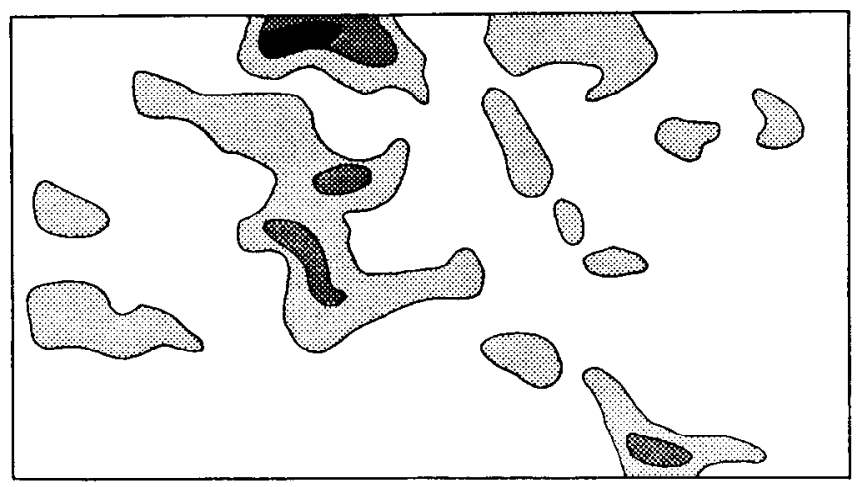

hours - hectare-1 month $^{-1}$

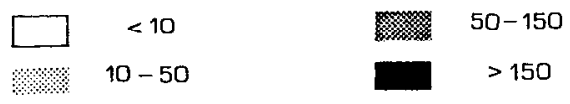

Fig. 2. Observed spatial patterns of grazing on the study area.

(A) growing season (April through October);

(B) dormant season (November through March).

(6) Bogr-Eref (18.0\% of the study area), a lowland sandy soil type, occurred adjacent to or directly above drainages or basins and was similar to the upland sandy soil type. Several differences warranted classification as a separate community, however: (a) cactus was both less frequent and less abundant in biomass, (b) western wheatgrass and sedges were more important, (c) density of spreading buck wheat was higher, and (d) snakeweed was replaced by rabbitbrush. Soil texture was coarse and soils were deeper than in the upland type.

\section{Methods}

\section{Observations of Cattle Behavior}

The study pasture had been lightly to moderately stocked ( 8 to 12 yearling heifers) before this study. Number of animals in the pasture was adjusted at the beginning and end of the growing season to maintain modcrate stocking.

Cattle were tracked on foot for one composite 24-h period each month for 12 months. Each 24-h period was divided into six 4-h observation periods randomly assigned to days of the month. Time, location, and type of activity of the entire herd were recorded on topographic maps of the study area at 15 -min intervals. If 2 or more subsets of the herd were engaged in different activities or had split into subherds, location, activity, and size of each group were recorded. Paths of movement between points were also recorded. 
If type of behavior changed, the location of the transition was noted. Grazing was defined as any feeding behavior, either standing or moving. Movement without feeding was considered to be travel and not included in the analysis.

\section{Analysis of behavior data}

The study area was divided into 0.1 -ha cells, and grazing time was summed monthly for each cell. Paths between location points were assigned a total weight equal to that of one location point.

Seasonality was determined by cluster analysis of monthly plant community use. Horn's $R_{0}$ was used as the criterion of similarity (Horn 1966). Seasonal grazing models were derived by multipleregression analysis (Senft et al. 1983). A pool of independent variables was assembled, and values for each variable were assigned to each cell. Variables in the pool included topographic factors, frequencies of 22 plant species, and percent cover of dominant perennial grass species. Values of topographic variables were obtained from an enlarged USGS topographic map (Fig. la). Plant frequency and cover data were obtained from detailed surveys taken during the US/IBP Grassland Biome Study.

Biomass and nitrogen (crude protein) content data provided additional independent variables. Aboveground biomass was sampled by harvesting on 4 dates (June, July, September, and November, 1981). Herbage was clipped within five $0.5-\mathrm{m}^{2}$ circular plots on 4 sites in each plant community. Vegetation was separated into 6 categories: (1) blue grama and buffalo grass, (2) sedges, (3) western wheatgrass, (4) scarlet globemallow, (5) other grasss, and (6) other forbs and half-shrubs. All vegetation samples were oven dried at $60^{\circ} \mathrm{C}$ for $48 \mathrm{~h}$, weighed, and ground in a Wiley mill with a 2-mm-mesh screen. Nitrogen content was determined by a modified micro-Kjeldahl method.

Table 1. Breakdown of observed graxing time by plant community (percent).

\begin{tabular}{|c|c|c|c|c|c|c|}
\hline \multirow[b]{2}{*}{ Month } & \multicolumn{6}{|c|}{ Plant Community ${ }^{1}$} \\
\hline & Buda-Bogr & Buda-Agsm-Carex & Agsm-Dist & Bogr-Oppo & Bogr-Eref-Oppo & Bogr-Eref \\
\hline June & 13.8 & 16.2 & 9.3 & 22.4 & 3.9 & 34.4 \\
\hline July & 24.8 & 14.9 & 11.1 & 22.6 & 7.5 & 19.1 \\
\hline August & 13.1 & 17.2 & 4.1 & 28.0 & 8.3 & 29.3 \\
\hline September & 19.8 & 23.9 & 7.0 & 15.9 & 3.6 & 29.8 \\
\hline October & 30.4 & 14.8 & 8.4 & 24.7 & 3.8 & 17.9 \\
\hline November & 20.3 & 4.1 & 0.0 & 48.0 & 13.5 & 14.1 \\
\hline December & 32.0 & 16.2 & 0.0 & 40.5 & 3.3 & 8.0 \\
\hline January & 40.1 & 8.6 & 9.9 & 34.5 & 0.0 & 6.9 \\
\hline February & 21.0 & 14.1 & 13.4 & 34.3 & 13.1 & 4.1 \\
\hline March & 7.4 & 12.4 & 5.1 & 39.5 & 31.6 & 4.0 \\
\hline April & 12.6 & 27.0 & 9.6 & 22.6 & 1.4 & 26.8 \\
\hline May & 5.3 & 24.5 & 12.4 & 23.7 & 16.3 & 17.8 \\
\hline Annual Mean & 20.0 & 16.2 & 7.5 & 29.7 & 8.9 & 17.7 \\
\hline April-October Mean & 17.1 & 19.8 & 8.9 & 22.8 & 6.4 & 25.0 \\
\hline \multicolumn{7}{|l|}{ November-March } \\
\hline Mean & 24.2 & 11.1 & 5.6 & 39.4 & 12.3 & 7.4 \\
\hline Percent pasture area & 15.6 & 11.8 & 8.0 & 37.7 & 8.9 & 18.0 \\
\hline
\end{tabular}

Species symbols are defined in text.

Table 2. Breakdown of observed grazing time by topographic zone (percent).

\begin{tabular}{|c|c|c|c|c|c|c|}
\hline \multirow[b]{2}{*}{ Month } & \multicolumn{6}{|c|}{ Topographic Zone } \\
\hline & Ridgetops & $\begin{array}{c}\text { South } \\
\text { facing slopes }\end{array}$ & $\begin{array}{c}\text { North- } \\
\text { facing slopes }\end{array}$ & $\begin{array}{l}\text { Draws } \\
\text { Lowlands }\end{array}$ & Fencelines & Watering Area \\
\hline $\begin{array}{l}\text { June } \\
\text { July } \\
\text { August } \\
\text { September } \\
\text { October } \\
\text { November } \\
\text { December } \\
\text { January } \\
\text { February } \\
\text { March } \\
\text { April } \\
\text { May }\end{array}$ & $\begin{array}{r}3.6 \\
1.5 \\
7.4 \\
0.0 \\
2.3 \\
15.9 \\
17.7 \\
10.9 \\
16.6 \\
6.4 \\
6.3 \\
3.9\end{array}$ & $\begin{array}{l}32.1 \\
23.2 \\
32.4 \\
18.9 \\
31.9 \\
34.0 \\
32.0 \\
13.8 \\
26.2 \\
65.4 \\
21.7 \\
31.0\end{array}$ & \begin{tabular}{r|}
4.9 \\
20.3 \\
25.3 \\
36.6 \\
16.9 \\
37.1 \\
27.6 \\
53.0 \\
17.4 \\
12.8 \\
29.7 \\
29.8
\end{tabular} & \begin{tabular}{r|}
37.2 \\
22.1 \\
15.6 \\
37.0 \\
26.8 \\
8.1 \\
14.6 \\
15.1 \\
33.9 \\
15.4 \\
40.2 \\
32.0
\end{tabular} & $\begin{array}{r}16.5 \\
20.9 \\
16.9 \\
5.6 \\
19.6 \\
0.6 \\
4.9 \\
3.3 \\
2.6 \\
0.0 \\
0.5 \\
3.3\end{array}$ & $\begin{array}{r}5.7 \\
12.0 \\
2.4 \\
1.9 \\
2.5 \\
4.3 \\
3.2 \\
3.9 \\
3.3 \\
0.0 \\
1.6 \\
0.0\end{array}$ \\
\hline Annual Mean & 7.7 & 30.2 & 26.0 & 24.8 & 7.9 & 3.4 \\
\hline April-October Mean & 3.6 & 27.3 & 23.4 & 30.1 & 11.9 & 3.7 \\
\hline $\begin{array}{l}\text { November-March } \\
\text { Mean }\end{array}$ & 13.5 & 34.3 & 29.6 & 17.4 & 2.3 & 2.9 \\
\hline Percent pasture area & 8.4 & 29.5 & 27.2 & 21.7 & 11.3 & 1.9 \\
\hline
\end{tabular}




\section{Results and Discussion}

\section{Observed Grazing Areas}

A fine spatial resolution (i.e., 0.1 ha) was used in the study of cattle distribution to avoid bias from arbitrary division of the study area. The 2 breakdown schemes most frequently used in previous research have been plant communities (soil-plant associations or range sites) and topographic zones (e.g., ridgetops, slopes, bottoms). Since these categories are not independent in many areas, there is some uncertainty as to whether or not the zones reported were actually the zones selected by grazing cattle. Our data indicated that plant communities were the spatial units cattle selected for grazing, especially during the summer months, when cattle highly preferred the Buda-Agsm-Carex community. In addition, a zone immediately surrounding the watering area was preferred at all times of the year.

\section{Seasonal Patterns of Grazing}

Cluster analysis of monthly patterns of community use revealed 2 seasonal patterns of grazing (Tables 1 and 2). The first seasonal cluster consisted of the growing season months (April through October). Mean similarity among monthly community use patterns was $95.6 \%$. The second seasonal block was the dormant season (November through March).

Intermittent drainage channels and adjacent communities were heavily grazed during the growing season (Fig. 2a). Lowland plant communities (38\% of the pasture area), received $54 \%$ of growingseason grazing (Table 1). Because grazing was intense near the watering tank (Table 2), the surrounding plant community (BudaBogr) was heavily grazed. However, a fouled zone with a radius of $60 \mathrm{~m}$ around the stock tank was virtually ungrazed.

With the onset of the dormant season, grazing preference shifted to uplands and ridgetops (Fig. 2b). During this period, upland plant communities (Bogr-Oppo and Bogr-Eref-Oppo) and the community near water (Buda-Bogr) accounted for $66 \%$ of observed grazing time (Table 1). The portions of total grazing time allocated to different communities displayed greater month-to-month variability during winter than during the growing season.

\section{Analysis of Seasonal Grazing Patterns}

Consistent seasonal grazing patterns suggested some underlying cause. The first step in analyzing of factors contributing to distribution was construction of predictive models. Significant predictors of seasonal patterns of grazing and the mathematical form and coefficient for each variable are listed in Table 3. Each seasonal grazing pattern had its own set of predictors. Except for proximity to water (1/distance), predictors for each season consisted of a series of site-quality indicators. During the growing season, percent frequency of western wheatgrass was an important predictor. a)

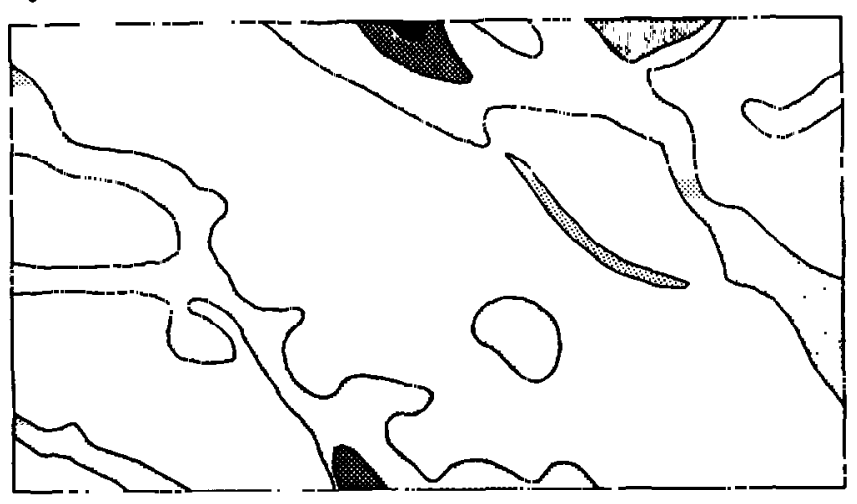

b)

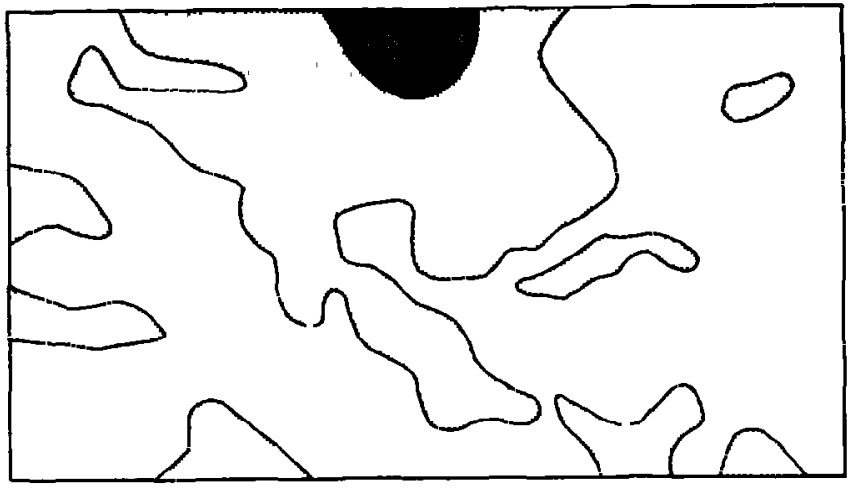

hours ' hectare ${ }^{-1} \cdot$ month $^{-1}$

$\begin{array}{lll}\square<10 & 50-150 \\ 10-50 & >150\end{array}$

Fig. 3.Predicted seasonal patterns of grazing on the study area: (A) growing season;

(B) dormant season.

This species was abundant in drainage channels (Buda-AgsmCarex community) and on saline sites (Agsm-Dist community). Frequency of spreading buckwheat, an indicator of sites with sandy soils, was also positively correlated to grazing. Frequency of

Table 3. Coefficients in the seasomal graxing models.

\begin{tabular}{|c|c|c|c|c|c|c|c|c|}
\hline \multirow[b]{2}{*}{ Season } & \multicolumn{8}{|c|}{ Independent variable ${ }^{1}$} \\
\hline & $\begin{array}{c}\text { Proximity } \\
\text { to water }\end{array}$ & $\begin{array}{l}\text { Oppo } \\
\text { freq. }\end{array}$ & $\begin{array}{l}\text { Agsm } \\
\text { freq. }\end{array}$ & $\begin{array}{l}\text { Eref } \\
\text { freq. }\end{array}$ & $\begin{array}{l}\text { Sihy } \\
\text { freq. }\end{array}$ & $\begin{array}{l}\text { Bogr } \\
\text { rel. abund. }\end{array}$ & Constant & $r^{2}$ \\
\hline Growing (Apr-Oct) & 438.0 & -.104 & .316 & .039 & - & - & 4.30 & .460 \\
\hline Dormant (Nov-Mar) & 350.0 & - & - & -.010 & -.109 & .014 & 0.50 & .269 \\
\hline $\begin{array}{l}\text { Mathematical } \\
\text { express in model2 }\end{array}$ & $\frac{1}{x_{1}}$ & $\mathbf{x}_{2}$ & $\mathbf{x}_{3}$ & $\mathbf{x}_{4}$ & $\mathbf{x}_{\mathbf{5}}$ & $100 \times\left(\frac{x_{6}}{x_{7}}\right)$ & c & \\
\hline
\end{tabular}

Species symbols are defined in text.

$2 x_{1}=$ distance from stock tank (meters)

$\mathrm{x}_{2}$ to $\mathrm{x}_{8}=$ percent frequency to plant species

$x_{B}=$ biomass of blue grama (Bogr) in community $\left(\mathrm{g} / \mathrm{m}^{2}\right)$

$x_{7}=$ biomass of all plant species in community, extuding pricklypear $\left(\mathrm{g} / \mathrm{m}^{2}\right)$ 
pricklypear cactus was negatively correlated to grazing, but results did not indicate clearly whether pricklypear was an indicator of poor sites or if it only interfered with grazing (Bement 1968).

The dormant-season grazing pattern was strongly related to the relative abundance of blue grama in the herbage, expressed as the ratio of blue grama biomass to total standing biomass multiplied by $100 \%$. Because cattle avoided plant communities with sandy soils during the dormant season, grazing was negatively related to buck wheat frequency. Cattle also avoided sites with relatively high frequencies of red threeawn (Artistida longiseta Steud.) and bottlebrush squirreltail [Sitanion hystrix (Nutt.) J.G. Smith], probably because of low vegetative cover.

Coefficients of determination for the grazing models (Table 3 ) were within the range of values found in previous studies (Cook 1966). All coefficients in the models were significant at the 0.001 level of probability.

Models were validated by comparison of observed and predicted patterns of grazing (Fig. 3). The predicted summer grazing pattern was very similar to the observed pattern. The winter grazing model, however, merged local areas of upland grazing into a single block on the central ridge. Both seasonal models accurately predicted plant-community use (Table 4). This result is not surprising, since

Table 4. Comparison of observed and predicted seasonal grazing by plant community (percent).

\begin{tabular}{lrrrrrr}
\hline \hline \multirow{2}{*}{$\begin{array}{l}\text { Plant } \\
\text { communityl }\end{array}$} & \multicolumn{2}{c}{ Growing season } & & \multicolumn{2}{c}{ Dormant season } \\
\cline { 2 - 3 } \cline { 5 - 6 } \cline { 5 - 6 } Buda-Bogr & Obs. & Exp. & & Obs. & Exp. \\
\hline Buda-Agsm- & 17.1 & 16.5 & & 24.2 & 21.5 \\
$\quad$ Carex & 19.8 & 20.3 & & 11.1 & 11.0 \\
Agsm-Dist & 8.9 & 12.3 & & 5.6 & 5.4 \\
Bogr-Oppo & 22.8 & 25.4 & & 39.4 & 41.3 \\
Bogr-Eref-Oppo & 6.4 & 6.4 & & 12.3 & 8.5 \\
Bogr-Eref & 25.0 & 19.1 & & 7.4 & 12.3 \\
Chi-square & & 3.06 & & & \multicolumn{3}{c}{4.09} \\
\hline
\end{tabular}

'Species symbols are defined in text.

2Tabular value, $5 \mathrm{df}, 0.01$ level of probability $=15.09$.

the models were dominated by plant-community variables. Predicted use of topographic zones (Table 5) was acceptable for the growing season but marginal for the dormant season. Winter predictions differed from observed behavior in that grazing was evenly partitioned among slopes and ridgetops, rather than being
Table 5. Comparison of observed and predicted seasonal grazing by topographic zone (percent).

\begin{tabular}{lccccc}
\hline \hline \multirow{2}{*}{$\begin{array}{l}\text { Topoggraphic } \\
\text { zone }\end{array}$} & \multicolumn{2}{c}{ Growing season } & & \multicolumn{2}{c}{ Dormant season } \\
\cline { 2 - 3 } \cline { 5 - 6 } & Obs. & Exp. & & Obs. & Exp. \\
\hline $\begin{array}{l}\text { Ridgetops } \\
\begin{array}{l}\text { South-facing } \\
\quad \text { slopes }\end{array}\end{array}$ & 3.6 & 8.8 & & 13.5 & 21.2 \\
$\begin{array}{l}\text { North-facing } \\
\text { slopes }\end{array}$ & 27.3 & 21.6 & & 34.3 & 22.1 \\
$\begin{array}{l}\text { Draws and } \\
\text { lowlands }\end{array}$ & 23.4 & 19.8 & & 29.6 & 28.1 \\
$\begin{array}{l}\text { Fencelines } \\
\text { Watering areas }\end{array}$ & 30.1 & 34.8 & & 17.4 & 16.4 \\
Chi-square & 11.9 & 13.1 & & 2.3 & 9.7 \\
\hline
\end{tabular}

'Tabular value, $5 \mathrm{df}, 0.01$ level of probability $=\mathbf{1 5 . 0 9}$.

weighted in favor of south-facing slopes (Table 5). The model smoothed observed patchy use into a diffuse pattern of upland use (Fig. 3). The observed patchiness was likely an artifact of sampling frequency rather than a reflection of actual grazing patterns. Because blue grama was the main dietary component, cattle grazed upland areas, where this species was plentiful. Since forage was not being replenished by plant growth, cattle moved to new areas after depleting initially preferred sites. Thus, as the dormant season progressed, a pattern of general upland use would have emerged. Our sampling may have recorded only parts of that pattern.

Both seasonal models predicted heavy grazing near water. Actually, a fouled and trampled zone around the stock tank discouraged grazing. The model was modified to exclude this fouled zone.

A factor not incorporated into the winter grazing model was snow cover. Because winter 1980-81 was mild and dry, observation periods never fell on a day with more than $10 \%$ snow cover. Light, patchy snow apparently did not affect winter grazing patterns. Qualitative observations during the following winter indicated that under a thick $(10-15 \mathrm{~cm})$, even blanket of snow, cattle graze areas with the tallest vegetation. On the study pasture, these areas were the upland sandy sites and yucca patches. Low stature of the Bogr-Oppo community, normally preferred in winter, prevented its use until significant snowmelt had occurred.

A serious deficiency of the seasonal grazing models was that spatial preference was not expressed as a function of forage quality

Table 6. Graxing preference for plant communities1.

\begin{tabular}{|c|c|c|c|c|c|c|}
\hline \multirow[b]{2}{*}{ Period } & \multicolumn{6}{|c|}{ Plant Community } \\
\hline & Buda-Bogr & Buda-Agsm-Carex & Agsm-Dist & Bogr-Oppo & Bogr-Eref-Oppo & Bogr-Eref \\
\hline $\begin{array}{l}\text { Growing season } \\
\text { (April-October) }\end{array}$ & 1.10 & 1.68 & 1.11 & 0.60 & 0.72 & 1.39 \\
\hline $\begin{array}{l}\text { Dormant season } \\
\text { (November-March) }\end{array}$ & 1.55 & 0.94 & 0.70 & 1.05 & 1.38 & 0.4 \\
\hline
\end{tabular}

'Relative preference was computed as the ratio of percent grazing time to percent pasture area.

2 Species symbols are defined in text.

Table 7. Grazing preference for topographic zones..

\begin{tabular}{lccccc}
\hline & \multicolumn{5}{c}{ Topographic Zone } \\
\cline { 2 - 6 } Period & Ridgetops & $\begin{array}{c}\text { South- } \\
\text { facing slopes }\end{array}$ & $\begin{array}{c}\text { North- } \\
\text { facing slopes }\end{array}$ & $\begin{array}{c}\text { Draws } \\
\text { and lowlands }\end{array}$ & Fencelines \\
\hline $\begin{array}{l}\text { Growing season } \\
\text { (April-October) }\end{array}$ & .43 & .93 & .86 & 1.39 & 1.05 \\
$\begin{array}{c}\text { Dormant season } \\
\text { (November-March) }\end{array}$ & 1.61 & 1.16 & 1.09 & .85 & .20 \\
\hline
\end{tabular}

'Relative preference was computed as the ratio of percent grazing time to percent pasture area. 
Table 8. Relationship of relative community preference with plant community variables. ${ }^{1}$

\begin{tabular}{|c|c|c|c|c|}
\hline \multirow[b]{2}{*}{ Normalized variable } & \multirow{2}{*}{$\begin{array}{c}\text { Correlation } w / \text { community } \\
\text { preference }\end{array}$} & \multicolumn{3}{|c|}{ Regression model } \\
\hline & & Intercept & Coefficient & Signif. \\
\hline $\begin{array}{l}\text { Standing N, preferred species } \\
\text { Biomass, preferred species } \\
\text { Standing N, live plants }{ }^{2} \\
\text { Standing live biomass }{ }^{2}\end{array}$ & $\begin{array}{l}.745 \\
.712 \\
.707 \\
.694\end{array}$ & $\begin{array}{r}.0023 \\
-.1604 \\
-.1809 \\
.0879\end{array}$ & $\begin{array}{r}.9442 \\
1.0863 \\
1.0635 \\
.9393\end{array}$ & $\begin{array}{r}<.001 \\
<.001 \\
.022 \\
.026\end{array}$ \\
\hline $\begin{array}{l}\text { Total standing } N \\
\text { Standing } N \text {, blue grama } \\
\text { Blue grama biomass } \\
\text { Total biomass }\end{array}$ & $\begin{array}{l}.586 \\
.530 \\
.521 \\
.451\end{array}$ & $\begin{array}{l}.1338 \\
.3814 \\
.1075 \\
.2665\end{array}$ & $\begin{array}{l}.7338 \\
.6305 \\
.8949 \\
.6120\end{array}$ & $\begin{array}{l}.007 \\
.016 \\
.019 \\
.046\end{array}$ \\
\hline
\end{tabular}

'Data from 5 plant communities for June, July, September, and November

'Data available for June and July only.

or quantity. This type of regression model has a limited predictive range and must be treated as an ad hoc model (Senft et al. 1983). New regression models are necessary to describe grazing patterns under new conditions. General models with wide applicability could be developed if vegetation properties attractive to grazing cattle were known.

\section{Spatial Preference and Vegetation Properties}

We had values for several potential factors that influence selection of grazing areas: (1) percent frequency of various plant species; (2) nitrogen content of various plant species; (3) aboveground standing biomass $\left(\mathrm{g} / \mathrm{m}^{2}\right)$, by species and by live and dead categories; (4) ratio of standing-live biomass to standing-dead biomass; (5) standing nitrogen $\left(\mathrm{g} / \mathrm{m}^{2}\right)$ of different plant species; and (6) standing nitrogen $\left(\mathrm{g} / \mathrm{m}^{2}\right)$ in live plant tissue. Standing nitrogen was defined as the product of percent nitrogen and biomass $\left(\mathrm{g} / \mathrm{m}^{2}\right)$ and is an estimate of crude protein available to grazing animals in a given community. Data for aboveground plant nitrogen and biomass were available at the plant-community level for June, July, September, and November 1981. Data for live:dead ratios were available for June and July 1981 .

Quantity and Quality of Forage Changes over Time

For grazing models to be general across time and space, independent and dependent variables must be converted to dimensionless numbers. Relative community preference (RCP) was defined as the ratio of the proportion of total grazing time spent during month $t$ in plant community $i\left(G_{i t}\right)$ to the proportion of total pasture area covered by plant community $i\left(\mathbf{A}_{\mathbf{i}}\right)$ :

$$
\mathbf{R C P}_{\mathbf{i t}}=\frac{\mathrm{G}_{\mathrm{it}}}{\mathrm{A}_{\mathrm{i}}}
$$

Preference values for plant communities and topographic zones are shown in Tables 6 and 7, respectively. Relative community preference was the dependent variable used in the analysis. Relative value of vegetation property (FC) in plant community $i$ at time $t$ was calculated as the absolute measured value for community $i$ at time $t\left(F_{i t}\right)$ divided by the mean level of the variable across the entire pasture. Mean pasture level of the independent variable was calculated as an area-weighted (A) mean of values across all communities. This type of model assumes that cattle seek the same property at all times when selecting grazing sites. Also, it assumes that cattle select grazing areas on a relative basis.

We derived relationships from data for 5 plant communities. The Buda-Bogr community was excluded from the analysis because preference was strongly influenced by proximity to water. Four relatively good predictors $\left(r^{2}>0.4\right)$ and four poor predictors $\left(r^{2}<0.4\right)$ of community preference were found (Table 8). Standing nitrogen $\left(\mathrm{g} \mathrm{N} / \mathrm{m}^{2}\right)$ in preferred plant species was most highly correlated $(r=.745 ; P<.001)$ to community preference. Plant species considered as preferred were blue grama, buffalo grass, western wheatgrass, and sedges for the growing season (June, July, September) and blue grama for the dormant season (Kautz and Van Dyne 1978). The variable second most highly correlated with community preference was biomass of preferred plant species, followed by standing nitrogen $\left(\mathrm{g} / \mathrm{m}^{2}\right)$ of live plant tissue and standing biomass of live plant tissue.

Except for the second independent variable in Table 8 (which was strongly correlated with the first), the best predictors of community preference were measures of both forage quantity and quality. Standing nitrogen is the product of the two, while measures of standing live tissue are measures of the abundance of high quality plant material. Thus, (1) both quantity and quality of the forage are important, (2) properties of species actually consumed are more important than properties of all species taken together, and (3) relative quantity or quality of forage in a plant community is more important than absolute quantity or quality in determining cattle preferences for grazing areas. Diet selection and selection of grazing areas are related. This relationship expresses itself through only a portion of the total herbage in the selection of grazing areas.

\section{Literature Cited}

Bement, R.E. 1968. Plains pricklypear: relation to grazing intensity and blue grama yield on the Central Great Plains. J. Range Manage. 21:83-86.

Cook, C.W. 1966. Factors affecting utilization of mountain slopes by cattle. J. Range Manage. 19:200-204.

Horn, H.S. 1966. Measurement of "overlap" in comparative ecological studies. Amer. Natur. 100:419-424.

Jameson, D.A. 1969. General description of the Pawnee Site. US/IBP Grassland Biome Tech. Rep. No. 1. Colorado State University, Fort Collins.

Kautz, J.E., and G.M. VanDyne. 1978. Comparative analysis of diets of bison, cattle, sheep and pronghorn on shortgrass prairie in northeastern Colorado, U.S.A. Proceedings of the First International Rangeland Congress, Soc. for Range Manage., Denver.

Senft, R.L., L.R. Rittenhouse, and R.G. Woodmansee. 1983. The use of regression models to predict spatial patterns of cattle behavior. J. Range Manage. 36:553-557. 